\title{
INTENSIFICATION OF THE PROCESS OF TEACHING A FOREIGN LANGUAGE USING GAME TECHNOLOGIES IN HIGHER EDUCATION
}

Статтю присвячено питанням інтенсифікації процесу навчання іноземної мови за допомогою використання ігрових технологій у вищих навчальних закладах. У статті висвітлюються позитивні моменти і даються деякі поради щодо удосконалення процесу навчання за допомогою ігрових технологій у внз.

Ключові слова: інтенсифікація, процес навчання, ігрові технології, вищі навчальні заклади.

Статья посвящена вопросам интенсификация процесса обучения иностранному языку при помощи использования игровых технологий в высших учебных заведениях. В статье освещаются позитивные моменты и даются некоторые советы относительно усовершенствования процесса обучения с помощью игровых технологий в вузах.

Ключевые слова: интенсификация, процесс обучения, игровые технологии, высшие учебные заведения.

The article is devoted to the issues of intensification of the process of learning a foreign language with the help of gaming technologies in higher education. The article highlights the positive aspects and gives some tips on improving the learning process with the help of gaming technologies in universities.

Gaming technologies of learning a foreign language contribute to the creation of an active, businesslike, necessary emotional environment. They help students to develop the ability to communicate on the subject of the language being studied, the ability to quickly find the necessary lexical units and terms, the keys to solve a problem in a game situation, sociability, concentration in the right situations, a sense of confidence in their abilities, the ability to express their thoughts by 
means of a foreign language, an assessment of the likelihood of using the knowledge gained in the chosen future specialty.

The game, according to scientists, is a type of developing social activity, a form oflearning social experience, one of the complex features of a person. Thus, the game can be viewed as a socio-pedagogical phenomenon. The originality of the game activity is manifested in unity with the practical activity and therefore is active, effective. The game reproduces not only the techniques and methods of work, but also many other human manifestations that reflect life in all its diversity.

The game of students can be viewed as a social and cultural phenomenon that is inherently associated with training and education as a personality-oriented activity. Naturally, the game of students is perceived as a natural type of their activities.

Keywords: intensification, learning process, gaming technology, higher education institutions .

Formulation of the problem in general. The modern stage of society's development is associated with the processes of globalization and integration, which require specialists not only to be competitive in the labour market, but also to master at least one foreign language. Mastering foreign languages opens up new opportunities for students, because it enables them to participate in exchange programs, to accumulate knowledge on the future specialty, to learn about advanced technologies and to expand their own outlook. For students of upper courses and postgraduates, a foreign language is required for participation in international conferences and work with literature on the subject of coursework, diploma thesis or dissertation. The above factors require continuous improvement of approaches to teaching discipline and intensification of the educational process; in this respect, the use of gaming technologies has an enormous potential [1].

Presentation of the main research material. Gaming technologies of learning a foreign language contribute to the creation of an active, businesslike, necessary emotional environment. They help students develop the ability to communicate on the subject of the language being studied, the ability to quickly find the necessary lexical units and terms, the keys to solve a problem in a game situation, sociability, concentration 
in the right situations, a sense of confidence in their abilities, the ability to express their thoughts in a foreign language, an assessment of the likelihood of using the knowledge gained in the chosen future specialty, etc.

The game, according to scientists, is a type of developing social activity, a form of learning social experience, one of the complex features of a person. Thus, the game can be viewed as a sociopedagogical phenomenon, an accessible way for students to increase their knowledge and master the world [7, 89]. The originality of the game activity is manifested in unity with the practical activity and therefore is active, effective. The game reproduces not only the techniques and methods of work, but also many other human manifestations that reflect life in all its diversity.

The game of students can be considered as a socio-cultural phenomenon, which is inherently associated with training and education as a personality-oriented activity [8,36]. Naturally, the game of students is perceived as a natural type of their activities (socio-cultural, communicative, correctional, entertaining, etc.). On the other hand, the game acts in a holistic educational process, as a means, principle, and method of organizing the life activity of student groups [9, 23].

The algorithm of the organization of the game includes: the choice of the game and its design; game offer to students; equipment of the gaming environment; breakdown into teams, groups; distribution of roles in the game; distribution of the main process of the game and the development of the game situation; the possibility of correcting the relationships of students in the game; completion of the game; result and analysis of the game.

The most common categories of game learning include: research, simulation games and non- simulation, based on the principles of problematic character, personality activity in learning, connection between theory and practice, the development of creative individuality in group work. The game activates the mental activity of students, allows to make the new process attractive and interesting, it has an emotional impact on the trainees. All this in aggregate is, in our opinion, a powerful incentive to increase the effectiveness of the learning process, a guarantee of high-quality mastery of the studied subject.

A business training game, as a rule, acts as a form of recreating 
professional activities, modeling relationship systems characteristic of this type of practice, and high-grade and high-quality knowledge of the subject within the program of study. According to the conclusion of many domestic and foreign psychologists and educators, an abstract method of teaching the subject, formal training turns into a rite of meaningless cramming, and the knowledge communicated to students has little in common with real life $[1,87]$.

The traditional practice of learning views its most important task in engaging students in the social and systematic experience of mankind. At the same time, the student turns out to be cut out of the space-time context, from the context of life and activity, and the goals of mastering already acquired knowledge are being imposed on him. Such educational information becomes the beginning and end of student activity.

The strongest motivating factor in gaming technology training are the teaching methods that satisfy the need of students for the novelty of the material being studied, the variety of exercises performed. The use of various techniques, in turn, helps to fix the phenomena associated with the studied subject in memory, to create persistent visual and auditory images, to maintain the interest and activity of the students. In philosophy, it is generally accepted that knowledge is a proven result of the knowledge of reality, its correct reflection by a man, which became a guide to action. This means that knowledge is not transcoding information into the language of brain structures. In order for information to become knowledge, the student must understand its meaning, that is, to restructure its past experience in view of the obtained new content in situations that are reflected in this information. To form a creative thinking, a creative individual of the student's personality, which is an essential attribute of the learning process with the usage of a professionally-oriented technology, the leading element is an unknown new knowledge, pattern or method of competent action that he has to learn independently or with the help of a teacher.

In accordance with the above, vocational training in a foreign language should be organized in such a way that learning activities act as a means for solving " quasi-professional " tasks by students. Modeling in educational activities situations close to reality allows finding the right solutions to professional and objective problems, being at the same time one of the effective ways to intensify the educational 
process.

One of the ways to simulate communication in the profile of the studied subject is speech games. The use of speech games in the process of teaching students a foreign language convinces that didactic games in higher education perform all four functions assigned to D. B. Elkonin , acting as: a means of development of the motivational sphere; a means of knowledge; a means of mental action and a means of developing arbitrary behavior. The game always involves making a decision - what to do, what to say, how to win. It is in the game that students learn social functions and norms of behavior. According to A.A. Verbitskiy game leads to the development $[2,15]$. The developmental value of the game lies in its very nature, for the game is always emotions, and where there are emotions, there is activity, there is attention and imagination, there is activated thinking.

Teaching the subject as a communication of like-minded people requires collective activity with regard to personal and interpersonal relations: a teacher is a group, a student is a student, a teacher is a student, a student is a group. The educational process, especially with vocational-oriented training, causes the interaction of all those present in the classroom. In this case, group activity has a positive effect on the personality of the student. With intensive study of the subject with the use of professionally-oriented technology of teaching, the teacher and students enter into certain social relations with each other. Success in such a study of the subject is the result of the collective use of all the opportunities for learning.

Language games as a kind of speech games not only contribute to the intensification of students actions in the classroom in a foreign language, but also develop their speech initiative. The gaming technology in a foreign language class allows to repeat and consolidate the learned lexical units and typical phrases, to diversify the forms of the lesson and to maintain the attention of students in the classroom. When conducting classes in a game form, it is advisable to use the exercises on the communicative assimilation of new terms, the most commonly used idiomatic expressions, the accumulation and active mastery of vocabulary for business communication within the topic being studied.

For practicing professionally significant listening skills, special language exercises are included in the used language games, which 
are focused on developing the skills to perceive, record and process the information related to the subject under study and its specificity. Experience shows that in order to work out forms of business communication, to form skills to operate with knowledge on the topic being studied in specific situations of the business professional community the most productive are communication exercises in the dialogue mode.

The technology of using games is a form of activity in conditional situations, aimed at recreating and assimilating social experience, formed in socially fixed ways of doing things, in objects of science and culture.

A distinctive feature of the game activity is its voluntariness, high activity and contact dependence of students. This is a special sphere of human activity, in which a person pursues no other goals than obtaining pleasure, satisfaction from the manifestation of his physical and spiritual abilities.

The variety of speech games we used was explained by a number of circumstances, in particular by the fact that in the practice of professional-oriented technology of teaching a foreign language by other authors, there is no professional-pedagogical orientation. So, E.I. Passov recommends the use of games in teaching a foreign language to achieve the following goals: a) the formation of certain skills ( in an example of the skill of posing a question when playing a puzzle); b) the development of certain speech skills, for example, after the studying of the topic "Housing" (students are interested in the game with the arrangement of furniture in the new apartment); c) learning the ability to communicate (for example, holding a competition for the most polite interlocutor or the most sociable person in the group); d) development of necessary abilities and mental functions ( for example, when playing a game for checking attention); e) the acquisition of new knowledge in the field of geography and language, which uses quizzes, lotto, travel, contests); f) memorization of speech material (for example, playing on the accompaniment of words with facial expressions and gestures, rhyming games, etc.) $[5,37]$.

In the process of learning a foreign language, we filled the future teachers of a foreign language with both their gaming speech activity and methodological content so that in the course of teaching the 
necessary material on the subject they would be in the position of active creators of learning situations. In order to organize the future teachers of reproducing and creative activity of students in combination, the new game is started by the teacher, who plays the role of lead, and then this role is conveyed to a well-prepared student.

In our opinion, to get the most effect from the game it is advisable to organize it in the form of competition. With the help of games, you can solve either a particular task - to improve phonetic, lexical, grammatical skills, etc.) or a whole range of tasks: to form speech skills, develop observation, attention, creative abilities, etc.

It is conditionally possible to subdivide all games into language and speech games. In terms of terminology, language games should be distinguished from speech or communicative games, educational games and business games.

Language games - a type of game tasks intended for the formation of pronunciation skills, lexical and grammatical skills and training of language phenomena.

Communicative or speech games are a type of game tasks, the purpose of which is to organize foreign language communication in the course of a communicative task.

Role-playing games are a type of game tasks that envisage the assignment of students to roles and the playing out of a communication situation in accordance with the theme and roles of students. In roleplaying games there is usually no problem situation.

Educational games are educational games in which the participants in the game learn the content of the subject matter.

Business games are usually used when teaching professional communication to create different situations of communication. In business games, a tense conflict situation is set. Business games allow the teacher to form not only professional skills and abilities, but also certain moral qualities of the personality: businesslike manner, efficiency, integrity, etc.

A characteristic feature of the game is its diversity. On the one hand, the player performs speech activity, the implementation of which requires actions related to solving very specific, and often nonstandard tasks, on the other hand, a number of aspects of this activity are conditional, allowing you to distract from the real situation with its 
responsibility and numerous prior circumstances. Diversity causes the developing effect of the game, helps to relieve psychological stress, because in case of failure the game can be repeated several times, which is not always possible in real life. For people who are focused on results, life failures are depressing factors that slow down the development of the personality. The game also contributes to the development, enriches life experience, creates prerequisites for success in real life.

The game, causing interest and activity of students, gives them the opportunity to express themselves in an exciting activity, contributes to a more solid memorization of terms, concepts and rules on the subject under study. Knowledge of educational material is a prerequisite for active participation in the game, and often a prerequisite for winning. So the game is used in vocational-oriented training, it makes it possible not only to improve already learned, but also to acquire new knowledge, since the desire to win makes you think of and remember everything that has been learned before. Another favorable condition for the game is its availability to students. The game, activating the desire of students to contact each other and the teacher, creates a situation of equality in speech partnership, thereby destroying the traditional barrier between the teacher and the students.

Obviously, the important thing is the ability of the teacher to captivate, "infect" the students with the game. To do this, the teacher must be very enthusiastic. Fixing errors should be carried out by the teacher imperceptibly, without distracting students from the game, an error analysis is done after the end of the game.

The logic of the game activity represents a certain sequence of actions: the teacher's operations in selecting, developing, preparing games, including students in the game activity, implementing the game itself, summing up the results of the game. For each type of game there is its own specifics of implementation. But in each of them there are typical operations and actions.

A business game, which is a special form of modeling a holistic educational process, as our experience shows, is based on knowledge of pedagogical theory. Designing and conducting a business game requires consideration of such criteria as: material problematics, simulation, game modeling, joint activities, communication, dialogue, and diversity. A business game allows to create subject and social contexts 
in future professional activities, and thus simulate, in our opinion, more adequate conditions for the development of the personality of a future professional, especially in the field of intercultural communication, as compared to traditional training.

The social order of the society determines the goals of teaching a foreign language. In recent years, the requirements for the level of training of teachers and teachers of a foreign language have sharply increased. The first priority is learning a foreign language as a means of communication. A graduate of a language department is no longer just a foreign language teacher, instructor or translator, but, above all, a universally educated specialist in international communication. Therefore, the business game in the educational process should be subordinate to the goals and objectives of training qualified specialists, developing, complementing and improving their professional skills.

In a real educational process in high school business game allows to solve many tasks simultaneously. This, as a rule, is a logical continuation of a specific theoretical topic, a practical addition to it, as close as possible to real conditions, it contains novelty and problems for solving; saturated with the necessary intellectual and emotional readiness of the participants to the game and creating an atmosphere of ease and search. We have repeatedly tested in the practice of teaching students the conditions for the effectiveness of educational games. We consider them the following: the content of the game should correspond to the level of preparation of the participants, the tasks of the participants, the rules of the game; the forms of the game (dispute, interview, press conference, etc.) and the goals of the game should be defined (generalization and fixation of the covered topic, activation of certain vocabulary on the most important topic, etc.); roles must be distributed, variants of potential decisions should be revealed; stages of the game with the allocation of the required time must be defined; the availability of the necessary props for the game should be checked.

In our practice in experimental groups, we mainly used predominant game training or pure game training. Under the game teaching, including the future profession, we have designed a technology of training in which the preference is given to the game, as the most effective form of education. As a result of this experimental teaching, in addition to the qualities mentioned above, the following features were identified, 
which make it possible to consider language and speech games as one of the most effective factors:

- the intensification of the educational process due to the preferential use of game learning is most effective and economical, since in this case, as a rule, no large expenditures are required to acquire means of its maintenance, and the form of the game itself is closest to the real professional conditions of future specialists;

- gaming training allows to design the learning process as a set of games of different levels, purpose and complexity, while pursuing the only goal - to prepare highly qualified specialists who meet all modern requirements and are able to start fulfilling their professional duties in full and on high professional level;

- educational games, by their nature and qualities, most successfully and effectively interact with other factors of educational and methodological support, can be used at any stage of teaching a foreign language.

\section{References}

1. Альошина О.М. Сучасні методи та технології викладання іноземних мов у ВН3. - 2012. - No30.

2. Вербицкий А. А. Активное обучение в высшей школе: контекстный подход. М., 1991, - 204c.

3. Дмитренко Т.А. Профессионально-ориентированные технологии обучения. М., 2003.-327c.

4. Дмитренко Т.А. Теоретические основы исследования интенсификации процесса обучения в высшей школе.- М., 2000. - 131c.

5. Пассов Е. И. Коммуникативный метод обучения иноязычному говорению. М., Просвещение, 1985, 2-е изд. - 222с.

6. Поликарпова Ю.О. Традиції та інновації у викладанні іноземних мов в умовах інтеграції України до світової спільноти. [Електронний ресурс]. -Режим доступу: http://www.academia. edu

7. Шмаков С. А. Игры - шутки и игры - минутки. М.,1993 - 111с.

8. Эльконин Д. Б. Психология игры. - М., 1999. - 304c.

9. Rivers, Wilga M. Communicating Naturally in a Second Language. - Cambridge: Cambridge University Press, 1996. - 243 p. 


\section{References transliterated}

1. Al'oshina O.M. Uchebno-metodicheskiye i metodicheskiye posobiya po VNZ. - 2012. - №30.

2. Verbitskiy A. A. Aktivnoye obucheniye $\mathrm{v}$ vysshey shkole: kontekstnyy podkhod. M., 1991, - 204s.

3. Dmitrenko T.A. Professional'no-oriyentirovannyye tekhnologii obucheniya. M., 2003.-327s.

4. Dmitrenko T.A. Teoreticheskiye osnovy issledovaniya intensifikatsii protsessa obucheniya v vysshey shkoleye.- M., 2000. - 131s.

5. Passov Ye. I. Kommunikativnyy metod obucheniya inoyazychnomu govoreniyu. M., Prosveshcheniye, 1985, 2-ye izd. - 222s.

6. Polikarpova YU.O. Traditsii i innovatsii v strane, gde yest' vse, chto svyazano s Ukrainoy i Shvetsiyey. [Yelektronniy resurs]. -Rezhim dostupu: http://www.academia.edu

7. Shmakov S. A. Igry - shutki i igry - minutki. M., 1993 - 111s.

8. El'konin D. B. Psikhologiya igry. - M., 1999. - 304s.

9. Rivers, Wilga M. Communicating Naturally in a Second Language. - Cambridge: Cambridge University Press, 1996. - 243 p. 